\title{
The manifestation of patriotism and social and political themes in Oriental poems Kashani's
}

\section{La manifestación del patriotismo y los temas sociales y políticos en los poemas orientales de Kashani}

\author{
Mohammad Reza Gholizadeh* \\ Mashhad Azad University, Iran \\ ORCID: https://orcid.org/0000-0001-9904-5898 \\ Seyed Majid Taghavi Behbahani \\ Mashhad Azad University, Iran \\ ORCID: https://orcid.org/0000-0001-5589-8012 \\ Hassan Basak \\ Payame Noor University, Iran
}

Received 02-01-20 Revised 04-20-20 Accepted 06-01-20 On line 06-03-20

*Correspondence

Email: d.ghmohammadreza3372@yahoo.com
Cite as:

Reza, M., Taghavi, S., \& Basak, H. (2020). The manifestation of patriotism and social and political themes in Oriental poems Kashani's. Propósitos y Representaciones, $\quad 8(2), \quad$ e544. http://dx.doi.org/10.20511/pyr2020.v8n2.544 


\section{Summary}

Khavari Kashani, nicknamed Fakhr al-Waizin and the language of Islam, which is one of the titles bestowed on him by Muzaffar al-Din Shah, is one of the poets of the constitutional period whose research on his poems has not been observed. In addition to being a poet, he is a journalist and with his poetry and prose tools, he has patriotic and political poems that show the poet's social commitment .He criticizes the Shah, the courtiers, and the foreign colonizers (Russia and Britain) in a strange way, and his poems on the homeland are among the best poems of the constitutional era. The reflection of many political and social events of this period can be seen in Oriental poetry .Patriotism, xenophobia, critique of moral, cultural and social vices, and freedom-seeking are among the themes found in his poems, which we will address in this article. In most of these cases, he has presented his message and critique by using allegory.

Keywords: East Kashani; Patriotism; Anti-Alienism; Social and Political Criticism.

\section{Resumen}

Khavari Kashani, apodado Fakhr al-Waizin y el lenguaje del Islam, que es uno de los títulos que le otorgó Muzaffar al-Din Shah, es uno de los poetas del período constitucional cuya investigación sobre sus poemas no se ha observado. Además de ser poeta, es periodista y, con sus herramientas de poesía y prosa, tiene poemas patrióticos y políticos que muestran el compromiso social del poeta. Critica al Shah, a los cortesanos y a los colonizadores extranjeros (Rusia y Gran Bretaña) de una manera extraña, y sus poemas sobre la patria se encuentran entre los mejores poemas de la era constitucional. El reflejo de muchos eventos políticos y sociales de este período se puede ver en la poesía oriental. El patriotismo, la xenofobia, la crítica de los vicios morales, culturales y sociales, y la búsqueda de la libertad son algunos de los temas encontrados en sus poemas, que abordaremos en este artículo. En la mayoría de estos casos, ha presentado su mensaje y crítica utilizando alegorías.

Palabras clave: Kashani del este; Patriotismo; Anti-alienismo; Crítica social y política.

\section{Introduction}

One of the prominent features of the poetry of the constitutional period is the enlightening and critical role of this type of literature. Tyranny and oppression, the destruction of the homeland, corruption and prostitution among the rulers, oppression and injustice, inefficiency of members of parliament, unfair situation in the judiciary and bribery of judges, superstition, scientific and cultural backwardness of society, including It is an unpleasant event that happened in this age. Thus, in this period, few poets can be found who have ignored these social adversities and have not felt a commitment to informing the people of the society. In other words, poets in this period had a realistic approach to society.

Khavari Kashani is one of the poets who has poems about the homeland; However, it has not been discussed and evaluated so far, and his poetic themes will be analyzed for the first time in this article. The main point in Oriental poetry is that the homeland has a fundamental role in all the small and large concepts and themes existing in the constitutional era, and all of his political poems can be called patriotic; That is to say, the reflection of the political, social and cultural events of this era, such as political and social criticisms, criticism of superstitions, criticism of government corruption, freedom, support for the Ranjbar class and the need for unity and coalition of parties, all fall into the form of Eastern patriotism. Because they depend on the destiny of the homeland for its happiness and misery; Therefore, these matters can be considered as sub-themes 
and sub-concepts of patriotism, which in this article will also be evaluated as a subset of patriotism.

His poems on the homeland are among the most outspoken and uncritical poems that have criticized political and social events in the constitutional era; Hence, the reflection of many political and social events of this period can be seen in Oriental poetry. The lack of comprehensive research in this regard has prompted the authors to shed light on the face of one of the most important critics and poets of this optical age by analyzing the themes of Kashani's Oriental poetry and examining the reflection of important events of the constitutional period in these poems.

\section{Research background}

Since the constitutional era and its literature are considered as important periods in the history of Persian literature, various researches have been done on the poetic themes of this period and the poetry of the prominent poets of this era; Among the books that have dealt with this very carefully is the valuable book Death or Modernity by Mashaallah Ajoudani, in which he discusses theories about constitutional poetry, stylistic developments, and the themes and themes of poetry of this period. Has reviewed and analyzed. (Ajoudani, 2002) Also, Yaghoub Azhand in his book Modern Literature in the Constitutional Period has dealt with the prominent figures of poetry of the constitutional era and publications and literary types in this period (Ajand, 2007).

However, so far no article or book has been reviewed and evaluated on Kashani's patriotic rhetoric and themes, and this article is considered a new work in this regard.

\section{Method}

This research has been done in an analytical and library way and has been studied and evaluated by studying the books and resources of the constitutional era and the poets of Kashani's Orientalism as well as his collection of poems, his influential poems and their main and secondary themes.

\section{Fundamentals of research}

In the constitutional era, as a result of the acquaintance of Iranian thinkers with the ideas of European culture, patriotism was introduced with a new concept and meaning, contrary to what was intended in the past. Prior to the constitution, the concept of homeland was very specific and limited, and mostly included the concept of birthplace; That is, where he was born or where he resided. "The old notion of the homeland is by no means the same as the notion that we have of the homeland after the Great French Revolution. "For the Muslims, the homeland was either a village or a city where they were born or the whole Islamic world." (Mahdian, 2009, p. 36). Even Aref, who has been named "national poet", says about this new approach from the homeland: "If I have not done any other service to music and literature, when I have composed the national anthem What does it mean that an Iranian did not know one of his ten thousand people? "They thought the homeland was a city or a village where humans were born." (Aref Qazvini, 2010, p. 231) The new concept of homeland begins with constitutionalism and the growth of nationalism in Iran and is accompanied by national and national self-awareness. And the single religious beliefs and even the birthplace.

Gradually, the homeland replaces the beloved in Persian poetry, and "interpretations and combinations such as the bride of the homeland, the homeland's lilac, the homeland's Zulaikha ... take the place of the old lover of Persian literature" (Bahar, 2008, p. 13).

The nationalism that has taken place in the form of patriotism is the idea of Islamic unity and freedom from the themes that Ajodani has mentioned for constitutional poetry (Ajdani, 1364 
pp. 24-26) Elsewhere in the homeland, he has listed freedom, Western civilization, and social and political criticism as among the main themes and themes of this period (Ibid., 2002, p. 218).

The nation and the homeland, freedom and tyranny, and the issue of women, the toilers, and ignorance and superstition are also recurring themes that, according to Ajand, are frequent in the poetry of poets of this period (Ajand, 2007, pp. 99-100) Shafiee Kadkani has also considered the main voice of constitutionalism to be more patriotism and social criticism. (Shafiee Kadkani, 2008, p. 34)

According to the analysis and evaluation of Oriental poems, the main and secondary themes in his poems can be divided as follows:

\section{Main topics}

Patriotism; Includes: a) Pride in the past and regrets the current situation b) Anti-alienation

\section{Sub-themes}

- Critique of moral vices, Cultural and Social

- Criticism of superstitions and emphasis on rationality and scholarship

- Criticism of the corruption of government parents and the judiciary

- Liberalism

- Supporting the suffering class and criticizing the poverty and housing of the people

- The need for unity and alliance of parties and the people

\section{Discussion}

\section{Life and themes of Kashani's oriental poems}

Sayyid Ahmad Fakhr al-Wa'izin was known as Khawani of the East; "On behalf of the mother of Haji Mir Masoom Khavari's mother, she is a potter who has given her the nickname of her ancestor (Khavari) on this occasion (Khavari, 1357, p. 17).

In his report on his life and how he received the titles of "Fakhr al-Wa'izin" and "Language of Islam" from Muzaffar al-Din Shah, he said:

"This servant, at the age of majority, in the shadow of his father's kindness and care ... spent his time studying science, the preliminaries of jurisprudence and principles ... At the age of eighteen, he set foot on the pulpit ... and gradually began to practice this technique. "Kamali was punished, I was praised by the elders and I became a companion of Mehsud ... In the year 1316 $\mathrm{AH}$, he traveled to Tehran. (Ibid: 21)

In addition to an excerpt from Hassan Naraghi's collection of Oriental poems published by Gutenberg Publications, Khavari has another book, The Book of Mahmoud, which he wrote in condemnation of opium and addiction to his son, and was published in 1289. Has published. Many Oriental poems have been published in the newspapers of that time, such as Soraya, Mizan, and Majles, from which he was the editor and editor-in-chief of Mizan newspaper.

Khavari Kashani, like most poets of this period, has taken a critical stance against the events of society in the constitutional era. After entering Tehran and observing the situation in the country, he did his best to raise awareness and express the lost rights of the people; His description of this situation is readable: 
"... During this trip, I was equally informed of the destruction of the country and the distress of the nation; I saw the country as a house where a group of people around it destroyed its foundation with shovels and pickaxes, and other groups of thieves were busy taking away the wealth of that house, and its inhabitants, some of them, were busy in a comfortable and collective sleep. "Let them quarrel with each other, and may the God of this house sometimes recite dhikr for the sleepy and sometimes associate with the worshipers, and sometimes help the thieves, when he admires the quarrelsome and creates the destitute." (Ibid: 21)

$\mathrm{He}$, who witnessed the destruction of the homeland, the poverty and homelessness of the people and the carelessness of the Shah and his followers, opened his mouth to criticize and blame Mohammad Ali Shah and his cabinet, and then on the pulpits, his goal was limited to "mentioning the good preaching and expression. Rights and the command to provide the means of civilization and the need to eliminate the need for foreigners and limit the oppressive possessions of the state "(ibid : 22).

Almost all of his non-religious poems can be included in the genre of political literature; Explicit critiques that have been uttered in the poet's language without fear and without fear of the consequences; As this poem was written in mourning for the murderer of Atabak Azam, Abbas Agha Tabrizi; Atabak was the supreme leader of the three Qajar kings, namely Nasser al-Din Shah, Muzaffar al-Din Shah, and Mohammad Ali Shah. Dear shrine, although my mourning is over

Nice of this new flower that sleeps in you happy and happy There is a place in you to revive that world Jesus is lying on your lap, Mana Mary

O world of zeal, O Abbas Agha Koz Sharaf You heal the wounds of the heart of the kingdom and the nation in healing An Iranian-Iranian Turk who is like a slanderer Moali Far Fereydoun Mohi Taj Jami The period of Yajuj, oppression and sedition is in the hands of zeal Because the construction of the iron dam is a strong barrier He said his mourning date was oriental From the six lulls of the resurrection of the world, man

(Ibid: 32)

East in $1317 \mathrm{AH}$. And in the city of Tehran, he joins a secret society that pursues nationalist and patriotic goals; However, all members of the association were punished for their critical articles and poems, which were eventually discovered in the form of a newspaper in the Mozaffar al-Din Shah dormitory. According to Ahmad Kasravi, in the constitutional history of Iran, Khavari was "pardoned from severe punishment and exiled to Kashan by the soft-spoken Mojahedin of the Shah." (Kasravi, 1975, p. 27) Of course, the Shah's interest in Khavari, who is also known for giving him special titles, has not been ineffective in this regard. Eventually, due to the enlightenment of the Eastern patriots in his poems, which call themselves "servants of the homeland", they intend to kill him and he is not allowed to live in his homeland and is forced to emigrate to Iraq; East in 1333 AH. (1293) died. In this section, we will deal with the themes of his poems, which are:

\section{Patriotism and Patriotism}

Since the literature of every age reflects the intellectual and cultural elements of that period, we have said that one of the main themes of the poetry of the constitutional period is patriotism. Attention to the homeland and criticism of its current state in a new way was the product of the necessities of the era of the Constitutional Revolution, which was manifested as a mission, 
commitment and commitment in the poetry of poets who had social inclinations. Adib al-Malik Farahani, Malek al-Sho'ra Bahar, Adib Pishvari, Abolghasem Lahouti and others have written poems praising the homeland and encouraging the people to preserve the homeland.

Patriotism in the constitutional period has two forms and two manifestations; First, the shape that "The Iranian homeland is considered in its current Islamic and even Shiite form; Like the patriotic poetry of Adib al-Malik and Sayyid Ashraf [Nasim Shomal] ... and some consider the homeland to be purely Islamic. "As can be seen in the poems of Aref and Eshghi." (Shafiee Kadkani, 2008, p. 22)

But the homeland, in the Eastern view, is an Islamic and Iranian homeland. That is At the same time, he is proud of the existence of national honors by observing oppression, injustice, and immutability in the protection of religious and Islamic values. Slow down.

The aim of the East in most of his poems is to excite the people and create a spirit of resistance and perseverance until the end of life to preserve the honor of the homeland; As he said:

There was no time for me to cry

It is enough for me to see the blood of my homeland

Your honorable body was torn to pieces and your limbs Each of them is defeated by one hundred enemies on each side

(Khavari, 1357, p. 134)

In many of his poems, he portrays the homeland as a mother, and the frequency of images related to it can be seen in the few remaining poems of this poet, compared to other poets. Other points that can be seen in these patriots, in addition to their longing and longing for the homeland, are the pride of the past and the comparison of the past with the present and regret of the current situation that has formed the structure of the eastern patriots. Also, in the form of these homelands, the poet's spirit of xenophobia and disgust with the occupation of Iran by Russia and Britain is reflected, which we will also address.

The disgraceful treaties that have plagued the homeland since the conquest of Qajar, and the extortion of Russians and British, which have had dire consequences, have always threatened the country's independence during the Qajar and Constitutional eras, causing poverty and misery.

"The Russians, with several million manats, bought the ruling class, the clergy, the merchants and the princes ... It was not the head of a famous man who was involved in the policy of the Russian aggressor government but to annex Iran to his vast country and reach the Gulf. "Fars did not fall" (Malekzadeh, 2004, p. 129).

Because of their interests in Iran, the Russians saw the constitutionalist movement as contradicting their goals;

"During the reign of Nicholas II, Russia's influence and interference in Iran's affairs increased, and the height of these interventions became apparent during the reign of Mohammad Ali Shah, and ... in order to prevent the achievement of Iran's constitutional results from the intensity of the Shah's actions in Iran. "He supported the constitutionalists" (Mahdian, 2009, p. 23)

The surviving and published Oriental poems show the poet's reaction to the events that took place in the pre-constitutional period until after the small dictatorship, in which the traces of Russian and British colonialism are evident. The Eastern Patriots of the Constitutional Era are as follows: 
The glory and authority of the motherland in the past and the unborn children today. The story of honoring the greatness of the past with the authority and glory of the country and comparing the constitutional period with that period is one of the recurring themes in the literature of the constitutional era; As Mirza Aga Khan Kermani has said about the homeland:

"O Iran, what is your happiness and happiness that you had in the time of Kiomars, Goshtasb, ¿Anoushirvan and Khosro Parviz?" However, such a shock and happiness next to Shaukat and the current happiness of the nations of Farangistan and the Yingi of the world is now like a candle in front of the sun; "But in the case of Iran, it's like light against the darkness of night" (Kermani, 2000, p. 19).

These concepts can be seen in the poems of most of the poets and writers of the homeland. For example, the poems written by Adib al-Malik Farahani under the titles of "National Anthem", "Song of Sorrow" and "National Anthem" are among the poems in which the desired themes are seen:

Chou was destroyed by the king of the country of Jam

The flag of science and art must be raised

Or:

O palace of Soleimani, what a ruin Iranian nation, what a misfortune it has been (Adib al-Malik Farahani, 2005, pp. 581-584)

In the following poem, Khavari also composed a lament for the homeland and portrayed it as a mother who once had children of Taj-Bakhsh and Jahangir:

O homeland of you, honor us, honor and glory O homeland, we give you the source of sorrow and grief O homeland, you have already had many children

Tajbakhsh and Jahangir and Homayoun Iqbal (Khavari, 1357, pp. 148-150)

According to the poet, Vatan, he had children such as Shah Ismail Safavid, Nader Shah Jahangir (cf. ibid .: 166-168) and Rostam and Esfandiar and Sam Savar (cf. ibid .: 186) as if to remind him and mention him. The glory of Iran and previous kings in the language of the motherland is a source of consolation for the poet and he has expressed it with regret:

It's as if they don't remember your son Farzaneh

King Ishmael is the father of the world

Or have they forgotten the difficulty of neglect?

From the worldview of Nader Shah Afshar, homeland

(Ibid: 166-168)

But despite the happy times that have been portrayed for the homeland in the past, the children of the homeland are illegitimate and asleep during the constitutional period and want to sell their mother out of greed:

O your children will want in dreams and strangers You are poisoned by the stars of Pamal $\mathrm{O}$ infallible homeland, your children are a group of greedy people Until the seller takes you to the broker country

(Ibid: 149) 
In another poem, Mam Watan speaks to the incompetent children of today after defending the heroism of his proud children of old, who have preserved his infallibility with their blood, and laments:

The skirt of my infallibility is not contaminated Enough of the shrouded body of the shrouded garment With all the suffering that happened to my children Strangers are now my intentions of trickery If all else fails, get ideas from others You can't talk about honor anymore Among the nations of zeal and honor and dignity You can't lift your neck from now

(Ibid: 153-155)

In this poem, the addressee of the homeland (poet) blindly responds with the hope that "the wind of sedition" cannot extinguish the "torch of the Qur'an" and that "Musnad Jam" will not replace "Ahriman"; These verses clearly show that Iranians smell Dan and Islam are both important in the East.

Don't let the flames of the Qur'an burn

1 Don't be a jerk instead of a devil

If the old races left your lap

Like Jamshid, Choo Kavous, Ghobad and Bahman

Now you have Mahin children too

Your wedding party is like the sky of your weddin

(Same)

These concepts mentioned in Oriental poetry have been common among writers and poets of the constitutional era; The same can be seen in the article published in the newspaper Habal alMuttin:

"Iran, Iran, Iran! You are our natural mother, ... you are the one who will eventually embrace your illegitimate or illegitimate children like Shirin Jan ... Iran! How miserable you were as a mother who was so unkind to the children of God and the carelessness of the children who did not spare any effort to preserve the nameless, shamelessly stretched Aghyar's foot in the sanctuary of infallibility with their own hands, lovingly competed; ... Some new husbands have thought of you for the great west. "Enough of your children's cruelty, because of the nature of nature and natural immaturity, they want to extend the hand of the ernootes [Sah: Erneot, meaning desert giant and rude] to the unfamiliar." (Habal al-Muttin (Calcutta), fourteenth year, p. 6, p. 1; quoted by Mohammad Khan, 2004, pp. 178-179).

The purpose of composing such poems and speeches is to strengthen the spirit of the disappointed and defeated people and to encourage them against the oppression of their foreigners and agents inside the country. As he said: "O Iranians with importance ... O brothers with zeal! "The homeland is a real mother ... why don't you come to your senses ... why are you ruining the national honor?" (Same)

\section{Alienation}

Opposition to foreign interference in the current affairs of the country and hatred of their extravagance towards the colonization of Iran are other themes addressed by the poets of the constitutional period. This concept in Oriental poetry is a subset of his homeland and should be examined and evaluated under his homeland. 
The contract was signed in 1907. It led to the unification of Russia and Britain and the division of Iran among them, causing the anger and hatred of the general public from foreigners and agents inside the country; The reflection of this event by the poets, with the aim of informing the society and creating a spirit of xenophobia and resistance against the oppressor, has a special effect on their poetry; In a way that few poets can be traced back to this period who did not react to this contract out of pain and impact; Adib (2005, p. 12) with a bitter irony called Russia and Britain "Yar Arabdeh Joo" and "Opponent of Breaking the Covenant" who have taken over the homeland:

On the right side of the car is a car On the left side the opponent breaks the covenant

And Bahar said: He made a covenant with Russia and the north and the south In two different lines, he misspelled From west to center and from east to north He surrendered to the savage enemy (Masrat, 2001, p.553)

Khavari, considering his freedom-seeking and xenophobic spirit, has made his poem a tool for informing and informing about this, and instead of his poems about Russia and Britain, he has interpreted "neighbor", "uninvited guest", " He has a "foreigner", "alien" and "devil" and has referred to him as "Saba" and the animal; Because these neighbors have torn the honorable body of the homeland a hundred times and each of them has taken a member (Khavari, 1357, p. 135); The two neighbors have not violated the right of proximity and have constantly incited sedition in the right of the homeland and have been thinking of harassment:

Russia and England have songs for our property Two neighbors on both sides have narrowed the field for us

(Ibid: 143)

Guests who did not respect the house and the owner of the house and set fire to their liver and attacked the body of the owner like an animal:

This poor nation is like a butterfly in the fire Use your drink Lose that unwanted guest One hundred regrets from Iran I didn't hear any guests coming into any house It is not possible This rule is for Saba, not man One hundred regrets from Iran (Ibid: 137)

"The issue of Russian-British intervention in the situation in Iran, which began during the reign of Agha Mohammad Khan and reached its peak during the reign of Nasser al-Din Shah, became a direct and obvious intervention during Muzaffar al-Din Shah's reign." (Mohit Tabatabai, 1987, p. 97) To the extent that Khavari has expressed his anger that these strangers have exceeded the arrogance and put their hands on the neck of the homeland:

It is a pity that with such beauty and kindness Until the stranger touches your neck

(Ibid: 166)

Strangers who have sharpened their greedy teeth and wanted to catch their homeland; Observing and regretting the East by observing these matters is that the indifference of the people has caused the cunning of the foreigners: 
And a stranger from the sharp greed of the tooth 1 with the intention of catching Iranian property

Where is our zeal and fairness that is alien

Zechariah and sedition slow down the house of the innermost house

(Ibid: 147)

With these descriptions, Khavari tried to convince the people of the danger of aggression and sedition by foreigners:

The seditions that took place in this property are the flames

These two neighbors do this from the south to the north

The Russians incited Rahim Khan and his son

He lost so many people and property

The British, on the other hand, are inciting sedition

To take independence from our homeland

(Ibid: 166)

Pictures and themes are evident in all homelands that speak of Oriental xenophobia; The Russians and the British are asking for all the help and support from this sad mother. A homeland that once had no children. He has been and has been Mehsud Aghyar, but now, with the defects of the zeal of his children, a stranger has proposed to him (Ibid: 186) and his illegitimate children, with zeal, have made the pure skirt of this mother a seductive assembly of the seditionist enemy. (NK: Same: 225)

\section{Critique of moral, cultural and social vices:}

The constitutional movement in Iran followed modernist developments that were precisely shaped by the cultural and social situation of Iranian society. The turbulent situation and the general backwardness of the society was due to the ancient intellectual and cultural fields that had dominated and diseased the spirit of the Iranian society over the centuries. When the thinkers of the constitutional era tried to explain the new and needed phenomena of society to the people, they encountered obstacles that stubbornly opposed modernity; These obstacles included ignorance, bigotry, superstition, and moral vices that blocked the path to reform and slowed it down. For example, lying, ugliness and innocence are among the moral vices mentioned by Ashraf al-Din Gilani:

Innocence and disgrace

La religious and lying Ugly and ugly acts

These are all new fashions In desperation, it is very hopeful

(Gilani, 1326: 164)

What is remarkable about the Eastern social criticism is that he did not consider only Russia and Britain to be the cause of the calamities and misfortunes of the people and Iran; He attacked some of the wrong customs and behaviors of the people and social problems such as money-worship, selfishness, carelessness and lack of zeal for the situation in the homeland, and expressed his hatred of these moral vices and criticized the bad traits of the people of the time. He has also called these matters effective in the misery of the homeland:

In circles called the love of the homeland

We are looking for money and blood

Russia brought troops to our kingdom

We are comfortable and unaware 
Like Gorgan, he is cruel

We all think of each other

We cry when we talk

Sometimes we behave in a polite and apologetic manner

Until we wake up and sedition

Our day is dark and our work is dark

(Khavari, 1357: 173-174)

In the following verse, Khavari also criticizes some other ugly customs and ethics of the society and introduces them as the cause of the lost Iranian glory:

From our hypocrisy, greed, negligence and ignorance

It has degraded our dignity and honor

(Ibid: 166)

In the Eastern view, all these factors have caused people not to pay attention to the homeland, and this has angered him; To the extent that it says:

Give your home to a stranger This is not the job of any animal

(Ibid: 177)

In the following allegorical poem, he considers the lack of zeal and desire for power and government positions as factors that have troubled Iranians and prevented them from paying attention to the homeland. So much so that Russia and Britain have taken over their home from both sides and are taking over the house without war or bloodshed:

Go to the nest if the chicken is different

His zeal is full of all that he has Angels and the Russians are greedy for each other

I mourn for our home and our sitting

Let's fight each other for office and money (so what?)

$\mathrm{He}$ is recording the house of two neighbors on both sides

(Ibid: 147)

Similar to the theme mentioned in the above poems, Dehkhoda also has an allegorical poem whose idea is unlikely to have been borrowed from one of these two poets:

I still remember wisdom Who took slaves in the nest of chickens I had a hard time picking up my beak My tears flowed from the vein My father laughed when I cried Patriotic learning from chickens (Dehkhoda: 1361, p. 125)

\section{Criticism of superstitions and emphasis on rationality and learning}

When the thinkers of the constitutional era tried to explain the new and needed phenomena of society to the people, they encountered obstacles that stubbornly opposed modernity. These obstacles, rooted in ancient culture, were ignorance, bigotry, superstition, and moral vices, which in many cases blocked the way to reform and slowed it down. Iranian society in the Qajar era had degenerated for various reasons, one of the most important of which was superstition, ignorance, and ignorance that ruled the minds of the people. Such issues, while being the cause of backwardness and the existence of problems, take on another function after the crisis, which is 
more destructive than the primary role, and that is the stabilization of the status quo. At this stage, people find themselves so preoccupied with hardships and problems that they become materialistic.

The use of superstitious issues such as Raml, foresight, and magic "removes the suffering of thinking and the problem of rational analysis of everyday affairs from human beings and acts as a guide for such people." (Mullah Mohammadi, 2012, p. 78)

Among the cultural shortcomings and moral degeneration, the most notable issues for constitutional poets, including the Kashani East, were the ignorance and illiteracy of the people, which almost all poets, while pointing to the need for knowledge. And they emphasized the rationality. As Khavari said in the following poem:

The light of knowledge to every country becomes lightless Let his people be free from government and honor When science went away, we lost prestige and wealth Perfection, industry, luck, dignity and honor went

(Khavari, 1357, p. 145)

What the poet intends in this regard is the science of medicine, which seems to have become involved with superstitions and has increased the work of superstitious prescriptions:

Because the science of medicine did not cause people to be disabled

Because they are then humiliated Now our country is in a state of famine Miracles have become a sage and a beast

(Ibid: 145)

Medicine is an allegory that the East has made a mockery of those who, by entering the Senate, have been prescribing copies of ignorance to the people:

Pi Flows Chou made this version

They repeatedly added the Senate name to the version Someone who is not aware of the characteristics of the Senate

It is not a sign of nature and benefit and harm His medicine was nothing but ignorance Be disillusioned with his Muslim body

(Ibid: 146)

The homeland is sick, and the twisted version is the ignorant parliamentarians who have left this patient in the hands of a stranger who is sitting waiting for the death of his homeland because the Queen is waiting:

Patient's homeland and two hundred unfair opponents Instead of a closed back solution after a loss Patient and foreigner equal to it Headquarters like the Queen of the Kingdom to take advantage of it From the path of the greed of the physicians to the passion of obtaining floss From this senate they demand Russian service

(Ibid: 147)

\section{Criticism of the corruption of the parents of the government and the judiciary}

Justice is possible in the shadow of the law, and whenever things are done in a society under the shadow of justice and law, it leads to the prosperity and progress of society and the country, the 
strength of religion and government, and a government based on justice and justice. It is for the good of the nation and it is the cause of its stability and strength. In the religion of Islam, justice is of great importance and value, and many verses and hadiths have been mentioned in the necessity of administering justice and condemning the oppressor and the oppressor: "Allah is the Guardian of justice and virtue" (Nahl: 90) The people, except for the multiplicity of justice, are close to the righteous "(Ma'idah: 8). But the implementation of justice requires organizations that consider justice and fairness as the top priority of their work and its members seek justice.

After being appointed to the Ministry of Justice, Ali Akbar Davar, contrary to the constitution, applied for authority and, in order to consolidate his power, dissolved all the administrations and courts of justice throughout the country and caused many protests. (Masrarat, 2005, p. 256) Bribery and corruption in the judiciary have been further cited as a reason for the East, as other sections of the language community to criticize:

The people have come to life on the lips of this justice

With all our poverty and distress

The government has accumulated bribes and say cute This priceless government has given us the right to cheapen

(Khavari, 1357, p.183)

Malkum Khan's article on the "Principles of the Religious Religion" states:

"Why did God create the world of Iran and the people of Iran?" In order for some people to have a good time! What is the blessed name of this device? Parents of the causal government of Iran; ¿By what art have these honorable saints been so privileged? "The art is to make Iran poorer, more humiliated and more destructive than any other place on earth." (Mohammad Khan, 2004, p. 145)

Therefore, Khavari called the same lawyers of the nation and the parents of the government as thieves, traitors and bastards and said:

In the name of justice, one promotes oppression

In the name of Sharia, one should do justice

To any office that makes sense with your eyes

It is the story of a thief and the story of Ramal

Dressed instead of ugly adjectives

He has become a traitor

A bastard whose blood was permissible is someone

To allow the weak to be lawful to themselves

(Khavari, 1357, p. 152)

\section{Freedom}

Another voice of constitutional poetry is freedom and libertarianism. With the formation of the constitutional movement, poets joined the group of libertarians all the time and with the nation, and with their pen and foot, they openly fought and fought against the tyrants.

At this time, due to the lack of sufficient information, the concept of freedom and its consideration was not clear, unambiguous, but everyone measured it according to their own tastes and criteria; But what was certain was that freedom, as one of the important principles of the constitution, was inspired by the West; That is, a kind of Western democracy that was rooted in the emergence of new ideas and the intellectuals' acquaintance with Western governments, which was completely different from the previous concept of freedom in Iranian society and literature. "Before the constitution, the concept of freedom, which is synonymous with Western democracy, did not exist at all. "Freedom begins with constitutionalism, and this thinking is the result of the 
Great French Revolution and the British Industrial Revolution and its aftermath." (Shafiee Kadkani, 2008, p. 35)

Prior to the constitution, freedom in Persian literature had a variety of effects. In the mystical works of Rumi and Attar, freedom meant liberation from the prison of the body and flight to the kingdom. Another meaning that was generally given in non-mystical texts of freedom of will has been to be released from prison, and the imprisonment of Saad Salman and Khaghani and others is full of this meaning.

But in the constitutional period, the concept of freedom in the sense of freedom of the pen, freedom of speech, freedom from tyranny, freedom of choice and freedom from the veil appears; Also, "equality of all members of the nation, with any belief, creed, religion, or creed, before the law, has been one of the theoretical ideals and fundamental principles of constitutionalism." (Ajoudani, 2002, p. 144) Therefore, each of the constitutional poets has taken a view of freedom from their point of view and sometimes criticized the non-realization of it.

Khavari called science and perfection the light of the torch of freedom and considered freedom as a blessing from God's grace and mercy; He cited freedom of expression as one example of freedom:

Every wise man who is not free, he speaks Certainly not the truth From the knowledge of his words lies All his wisdom and grace remain hidden

(Khavari, 1357, p. 184)

Another example of freedom in the East is the freedom of the people from the tyranny of the rulers; In a way, this will lead to the destruction of science and virtue and the destruction of the homeland; In other words, the poet called the lack of freedom the cause of the country's destruction and misery:

Every land that is not free his people In him, mercy, knowledge, perfection and grace of Majo If you were, freedom in this Iran There was no such thing as oppression

(Ibid: 185)

The utopia of the East is "the property of Europe" in terms of the abundance of freedom, which, unlike Iran, is very prosperous thanks to the "government of freedom":

Contrary to the property of Europe, which is with the people of consciousness The government of freedom has become so ordinary Chou is not an obstacle to the path of thought and imagination They hit the roof of Rifat on the roof of grace and perfection

(Same)

According to Khavari, the lack of freedom and the subsequent tyranny of the constitutional era have not only ruined the country but also ruined religion:

The divine decrees went to the wind of tyranny Religion was shaken by the foundation of tyranny

(Ibid: 215)

Elsewhere, as is the custom in the East, the allegory reminds us of the value of the blessing of freedom by mentioning an allegorical account of the desolation of the desert; As this miracle, 
eating snakes and drinking salty water and being with a dog is preferable to being tied up and obeying another command:

Eat salty and bitter water and snakes Leaving the way of pleasure with this dog

Better a poor horse than no horse at all At the command of the princes, he returned to Damasaz

(Ibid: 241-242)

By intimidating the people and inciting them, he brings to life the hasty life that enjoys the blessings of freedom while living in the desert, reminds them of the dignity of his life, and asks them to protect themselves. Release the existing oppression and tyranny; Because the value of freedom is greater than human life:

Except for the patriots Wise wise wise

The Wild Wilderness of Mankind No matter how hard you try Don't try to be free The price of the sex of freedom if John

Make it easy (Ibid: 242)

\section{Supporting the suffering class and criticizing the poverty and housing of the people}

Other voices that are clearly heard in the poetry of the constitutional period are the issue of poverty and hardship of the suffering workers and the support of the poets who are committed to them. When the constitutional movement came to an end, Iran was in a very miserable economic situation. Poverty, misery, misery and misery had pervaded the country; Drought, famine and disease threatened people, especially the suffering, workers and farmers. The imposition of heavy taxes and huge court costs also made the situation more difficult. The poverty and misery of the people was so great that one of the European historians living in Iran at that time said: "Iranians who find a few copper vessels and a piece of carpet in their house are considered rich by the people." (Malekzadeh, 2004, p. 135)

In the meantime, poets with social tendencies, in fulfilling their mission, reflected the plight of the people, wrote down their lost rights, and created a new movement called "workers' literature". This tendency arose as a result of the simultaneity and connection between the Russian October Revolution and the Iranian constitution. This connection between intellectuals and libertarians outside Iran's borders, including Istanbul and Cairo, led to labor issues and global socialism flowing into Iran.

At this time, poets inside and outside Iran, inspired by this thought, spoke of the conflict between the worker and the capitalist and the equality of their rights. For example, Farrokhi Yazdi has published several articles in his Toofan newspaper, citing the unequal distribution of wealth and national resources as the main cause of misery and bankruptcy among the Iranian people. As he said:

"If we are poor, if misery is common in our country, the main reason is the inequality in the distribution of natural wealth ... The true happiness of our country begins on the day when the order of the present possessions changes; This power is available only to a sacred profession that has brought the oppressors and nobles to their knees everywhere and removed the foreheads of the poor from the soil; "This is the sacred word of socialism." (Storm of the first year, vol. 44, p. 1; quoted by Mohammad Khan, 2004, p. 261). 
Khavari has also defended the equality of human beings and their equal rights, and has warned of their equality on the basis of Sharia and wisdom:

All people are in human clothes They are equal in rights according to Islamic law and wisdom They are created equal to the power of God

Their rights were all the same

The system of the world is equal The permanence of the Bani Adam generation is equal

(Khavari, 1357: 193)

But the "disgrace" that the East considers the most disgraceful act in the world, and the characteristic of those who have exploited the toiling class of society, has disturbed these equality and damaged the equality of human beings. Has:

From the pride of acting to the world It wasn't worse for Dana

It was a great honor The people are bothering him

(Ibid: 188)

According to Khavari, all the benefits of the efforts of the weak class of society have been taken over by the rich class, and they owe their wealth and government to them:

Poor sufferers of half-baked barley bread From his government, Amir has filled the frame

Gone are the hardships of the poor They are proud of their bread Bloody businessman, old man, his clothes on The cruel tyrant sewed from Atlas of Thai

The annoyed farmer wears dry skin It takes a lot of effort to be in the sun

(Ibid: 192)

The impact of exploitative exploitation on the weak is not the only concern of this group; Rather, these oppressors, with their indifference and corruption, have led to the decline of the independence of the homeland and its innocence:

What good are these corrupt people? If the homeland collapsed, the decline of independence

The one who possessed zeal should not be satisfied

That the dignity of his homeland be overthrown

Put the name of the suffering fan on himself

Pulling the veil of cunning and the ugliness of deeds

(Ibid: 199)

The necessity of uniting the people and the coalition of parties in the parliament

The victory of the small countries of Transvaal and Japan over the two colonial powers of Britain and Russia, sparked hopes in their hearts.

The Iranian people and thinkers had revived; 
"At that time, the Trans-Italian-British War broke out; Then came the war between Japan and Russia. The bravery of a handful of transgender people and their masculine resistance to a great government, such as Britain and the defeats they inflicted on the army several times, as well as the ready Japanese troops and the co-operation of their commanders and successive turmoil. "They found it difficult to shake the Iranians." (Kasravi, 1975, p. 44).

That is to say, the thinkers had come to believe that with unity and solidarity, even your superpower could be defeated; After the small tyranny and expulsion of Mohammad Ali Shah from the country in $1328 \mathrm{AH}$. (1288), the greatest obstacle to constitutionalism was removed; Therefore, Khavari, out of hope and in order to strengthen the coalition and unity of the government, the parliament and the people, and in criticizing Mohammad Ali Shah, expressed his fear and apprehension:

O tyrant, let the immortal parties die Now, despite your fear, they formed a coalition You would be happy if there was a difference of opinion

Don't think like that before Amir Panjeh's turn from carrying a quilt

(Khavari, 1357, p. 213)

The unification of the parties and the unity of the people is the only way that Khavari like other thinkers of this period - introduces for the liberation and promotion of the homeland and resistance against the enemies; The idea came to the minds of Orientalists and other Iranian intellectuals and thinkers who gradually witnessed the fragmentation between government officials, members of parliament, and constitutionalists who were fed up with constitutionalism. But in reality they did not value it.

"Although the members of parliament were considered representatives of the nation and were elected by the people themselves, they were not loyal to the nation and the homeland for personal gain ... and cooperated with the ministers and other government officials in selling the country to foreigners." They did" (Mohammad Khan, 2004, p. 233).

"I urge the United States to refrain from interfering in the affairs of the United States," said Khawari, referring to the opportunistic situation in which all the lions once defended the constitutional arena and turned their backs on material and political situations.

That in the constitutional way to a hundred enthusiasm and haste

Where is the lioness attacking the evil sect?

These bosses are all entertaining themselves and the enemy of the homeland

Give each side a hand of oppression from Kane Jolan

Suddenly the constitutional fire was extinguished

Because he paid 100 tomans to the offices

(Ibid: 211)

He went on to call the unconstitutional dictatorship a seeker of gold and silver, whose zeal, ignorance, greed, greed, sedition, chaos, and oppression (ibid: 212) and the times of the people and the country have been ruined.

\section{Conclusion}

According to what has been said, Khavari Kashani was a poet, writer and journalist who had a clear and fearless language in political and social criticism. In his patriotic and political poems, his enthusiasm and interest in the country's situation is evident, and in xenophobia and libertarianism, he is one of the poets who has unequivocally criticized foreign enemies and the parents of the ruling government. 
The poet, who once received titles such as Fakhr al-Waizin and the language of Islam and royal disgrace on behalf of the Qajar Shah, criticized the political situation in the country, and was aware of the sensitive situation of Iran in the constitutional era against Russia and Britain. He takes the kings and composes poems to promote the name of the homeland, which indicates his social commitment.

Unfortunately, not all of Kashani's oriental poems are available, and the existing collection of his poems is an excerpt from his political and critical poems, and there are other gaps in his poems. However, despite this selection of poems, we have shown that Khavari Kashani has played a key role in informing and awakening the people of the constitutional era, and sociopolitical criticism, encouragement of patriotism through passionate patriotism, influential poems on xenophobia and emphasis. On uniting and empathizing with the enemy, he has made him one of the most influential and influential poets of the constitutional era. This article is the first attempt to evaluate and analyze his poems, and more accurate results can be obtained by compiling his other poems through sources and documents and newspapers of the constitutional period.

\section{References}

Adib al-Malik Farahani. (2005). Life and Poetry of Adib Al-Malik Farahani. By the efforts of Seyed Ali Mousavi Garmaroodi. Tehran: Qadyani.

Ajand, J. (2007). Literary Modernity in the Constitutional Period. Tehran: Publications of the Institute for Research and Development of the Humanities.

Ajoudani, M. (2002). Or death or modernity; Office in Constitutional Poetry and Literature. London.

Aref Qazvini, A. (1389). Divan of Poems. By the efforts of Mehdi Noor Mohammadi. Tehran: Sokhan.

Bahar, Mohammad Taqi. (2008). Poetry Divan. Tehran: Negah.

Dehkhoda, A. A. (1361). Divan of Poems. By the efforts of Mohammad Dabirsiyaghi. Tehran: Tirajeh.

Gilani, Ashraf al-Din. (1326). Nasim Shomal Book. Mumbai: Soltani Printing House.

Kasravi, A. (1975). Conditional history of Iran. Tehran: Amirkabir.

Kermani, M. A. K. (2000). Three written. By the efforts and editing of Bahram Choobineh. Germany.

Khavari, A. (1357). Life, Letters and Poems. Collector Hassan Naraghi. Tehran: Heidari Publishing House.

Masrat, H. (2001). Freedom Leadership (Life and Farrokhi Yazdi's poem). Tehran: Third Edition.

Mullah Mohammadi, A. (2012). Constitutional Poets (Analytical-Sociological Study of the Poems and Thoughts of the Poets of the Constitutional Era). Cultural Studies.

Mahdian, M. H. (2009). Memoirs: A look at the relations between Iran and Russia. Ministry of Foreign Affairs.

Malekzadeh, M. (2004). History of the Constitutional Revolution in Iran. Tehran: Sokhan.

Mohammad Khan, M. (2004). The Thought of Freedom in Iranian Constitutional Literature. Persian Research Center of Iran and Pakistan: Islamabad.

Mohit Tabatabai, M. (1987). Analytical History of the Iranian Press. Tehran: Besat.

Shafiee Kadkani, M. R. (2008). Persian poetry from constitutionalism to the fall of the monarchy. Tehran: Sokhan. 